\title{
Mediating Memory: Strategies of interaction in public art and memorials
}

\author{
Erling Björgvinsson and Anders Høg Hansen, Malmö University
}

\begin{abstract}
The article addresses how a selection of participatory art and memorial projects have engaged with public memory and interaction. The intention has to been to explore the tension between the artists' strategies and the actual life span and use of the art works by its audiences. The authors interviewed the artists Esther Shalev-Gerz, Alfredo Jaar and Rafael Lozano Hemmer (during 2008 and 2009) and examined specific works. In addition, one of the literally 'ground-breaking' works of process art by Robert Smithson, Partially Buried Woodshed, was included in the analysis of cases that have provoked interesting social or collective memory debates and community interaction around public art.
\end{abstract}

\section{Introduction}

In recent decades a common artistic strategy has been to create art forms and spaces that involve processes of interaction and change where the spectator's involvement is part of the purpose and outcome of the art project'. Working as an artist with processes and participation means engaging more actors and opening doors for volatile and unpredictable uses of the projects. This approach has been apparent in the work of Esther Shalev-Gerz and Jochen Gerz, Robert Smithson, Alfredo Jaar, and Rafael Lozano-Hemmer . Selections of their works are engaged with here; in particular examples that have drawn attention to a dynamic and unstable view on so-called public and collective memory (Young, 1993, 2000), meaning that more traditional forms of passive public commemoration and engagement with monumental art have been re-opened for new collaborative disputes and debates.

In this article we concentrate on public art forms which in various ways relate to memory and memorial practices viewed as changing and dynamic processes and ephemeral exchanges. The article in particular looks at how the artists address or question appearance and permanence in relation to memorial practices, the artists' approach to the site of intervention, the artists' strategies of engaging the publics in active participation, and the tension between the artist's intentions, and the actual life span and appropriation of the projects by its audiences.

In the course of the research we interviewed three of the five artists in question. Smithson is deceased. For the Harburg project, collaboration between Jochen and Esther Shalev-Gerz, we interviewed Shalev-Gerz only. We have examined the strategies of mediating memory - and accounts of the interactive processes through a variety of concepts encircling the social and public debates in relation to memory, such as the term pairs collective and collected memory (David Young), the concepts of appropriation (Henri Lefebvre (1974/1991), and as interpreted by Gunnar Sandin, 2003), and palimpsest (Andreas Huyssen, 1995). Bruno Latour's (2005) thinking in relation to dingpolitik and public assembling - as well as notions of temporality, ephemerality, and erosion and disappearance have also been explored. 


\section{Processual Art - Robert Smithson and Partially Buried Woodshed}


Robert Smithson's work in the 1970's played a significant part of initiating a wave of processual art in relation to specific sites. His earth works such as Spiral Jetty and Partially Buried Woodshed highlighted the relationship between the natural and built environment (Sandin, 2003, Shapiro, 1995). But it also explicitly dealt with history and the future by creating processual art in the present. Smithson incorporates a process of change and intervention into the present art work. Outside the Kent State University in Ohio, Smithson arranged, during a stay as visiting lecturer, in January 1970, to have truckloads of dirt shoveled over an old, abandoned woodshed until its central beams cracked and the woodshed was partially buried. Smithson then stopped here. Smithson had on the one hand speeded up the decay of the construction, relegating it to the state of a ruin by his vandalistic and palimpsestic over-writing (Huyssen, 1995) with mud and dirt. On the other hand, Smithson had also given the abandoned woodshed a new attention. Arts impermanence had been actualized and demonstrated. Man had now with art, as with so much else in nature, ambiguously brought an artifact (in the case a woodshed) into re-use or re-arrangement (palimpsest) - as well as arranged and accelerated its decay and deterioration. Smithson then left Ohio and donated the art work to the university. A few months after, USA was marked by demonstrations all over the country against recent developments in the war in Vietnam. Four students were shot down and killed around Kent State University on the 4th of May in the aftermath of President Nixon's announced engagement in Cambodia (a TV address 30 April) - and soon after a student went to the shed and wrote with white paint on its front 'MAY 4 KENT 70'. The woodshed now got re-contextualized and famous as ruin where the process of entropy at the annotated crumbling shed came to mirror the crumbling of American self confidence in Vietnam. It was cracking times around 1970. The inscription, an overwriting of the prior overwriting of mud-shoveling, turned a piece of work primarily concerned with entropy and nature's victory over man into a political piece. 


\section{Burning Down the House - Alfredo Jaar's Art Hall in Skoghall, Sweden}
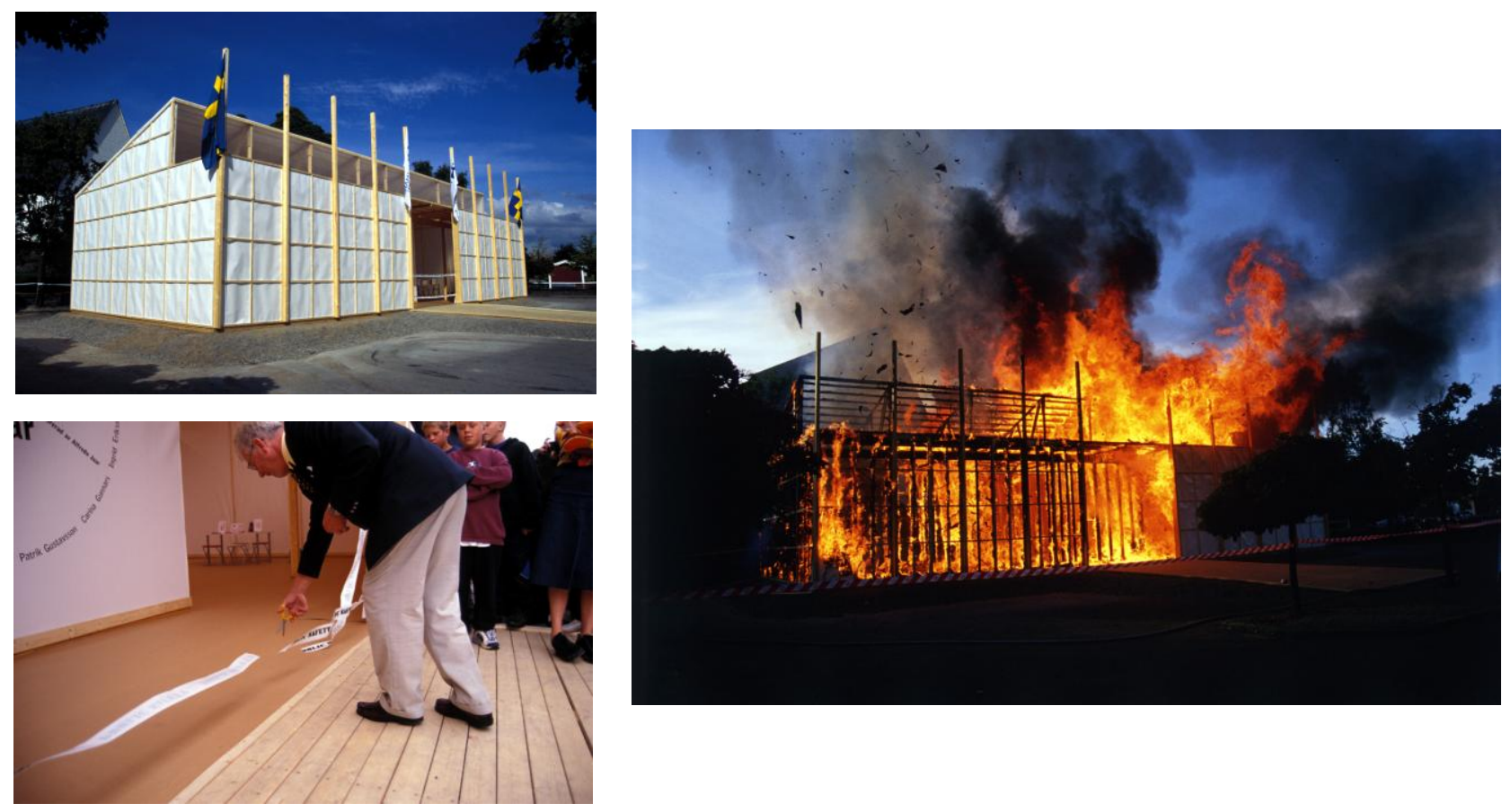

The Chilean born New Yorker Alfredo Jaar has carried out over 50 public art pieces that build upon specific concerns related to the sites he becomes engaged with. In addition, Jaar has also carried out numerous exhibitions within museums and galleries. In his public art works Jaar goes into a dialogue with local community engaging for example politicians and local inhabitants as well as using local buildings and locally produced materials. Although Jaar finds that his public art works are more rewarding than those exhibited within galleries and museums, he is ambiguous to the idea of involving "others" into his work since he also aims to plan or choreograph the artistic process.

Jaar's Art Hall project was part of the Public Safety Project coordinated by Jörgen Svensson ii. During the autumn of 2000 Alfredo Jaar had an Art Hall constructed in the small rural and industrial city of Skoghall, in central Sweden. The simplistic gallery was made entirely by the timber and paper from the town's main paper- and wood manufacturer, Enso. Skoghall had no art museum previously; it was largely conceived as a dormitory town with no civic space for art. 24 hours after the opening of the museum - with works by contemporary Swedish artists - Alfredo Jaar had the new art gallery burned to the ground in front of a public mass watching!

The Skoghall art hall project played with the idea of using the 'soul' or the material that had made this industrial town's people, its timber and paper, and give them something new they lacked - art! The timber of the local industry had now for the first time been married to contemporary art and a brand new gallery. A highly unusual coupling - and then quickly everything went from flames to ashes. A space for reflection was created while the townspeople could watch, smell and feel the heat of its timber and newly achieved art disappear in smoke. A sense of loss was created (Svensson and Sandén, 2000). After giving the public what they previously did not know about, Jaar violently ashed the idea, literally. He may here also have 
lured them into falling for art? What Jaar however had created was an unforgettable, brief and effective media spectacle. A glimpse of art, no more, no less: like a first love experience.

Skoghall citizens were however not all happy that its timber was being used by someone who - in the eyes of the viewer not accustomed to art in the public sphere - appeared to be an arsonist artist. We could have created a playground, as a citizen said (Jaar designed one later for free, but it was never realized, he says (Interview, 2008). Many Skoghall residents saw the interaction around the various works in Public Safety, not just as a debate on the emergence of art and change of Skoghall - but as much as a means of marketing Skoghall, to get on the map and attract tourists and business (Ferner, 2003, Svensson and Sandén, 2003). As a public artist you situate yourself in a context, in a moving environment, and you cannot know where it will take you or how people will use the work, as Svensson explains in Ferner (2003). Alfredo Jaar adds that he prefers public art because of the unpredictability, "in public art you loose control", he explains (Interview, 2008). However, his Skoghall project was strongly choreographed allowing little or no public intervention. Its magnificent and 'enlightening' theatricality however drew a mass audience to the site. In addition to the regional press coverage during the projects lifetime in 2000, the regional press has returned to the subject of the art hall in Skoghall many times. In 2007 Skoghall have had art works in an old hotel used as café and exhibition gallery. The writer notices "the closest the island [where Skoghall is located, eds.] has come to an art hall was the one in paper which was build and burned down during the art project Public Safety in 2000" (our translation, Bonnevier, 2007) ${ }^{\mathrm{iii}}$.

Jaar's art hall project was creating a memory of something the local population did not previously experience. The burning art hall became a memorial for a lack - and instead of imposing an art hall on the community it pointed towards a possible future. Now the community had been exposed to the idea - and it was up to them to establish an art hall all by themselves later on.

This spectacular piece is in some ways peculiar when seen in the light of Jaar's view regarding various strategies of engaging with art. He divides his work into three categories. One body of work is done for the art world, which is a world of fiction; another body of work consists of public interventions, which happen outside of what he calls the "white cube". "In these works I feel real, try to resolve real problem with people far removed fro the art world," Jaar says. He points out that over the years he has been engaged in 55 public projects and they have become important to him. "I receive invitations from all over the world." Finally, as a third category, he also engages in teaching art. Seen in this light it is peculiar that Jaar thinks that Skoghall is in a need of a white cube, which on the one hand creates a stable foundation for remembering but simultaneously, Jaar seems to imply, creates a strange fictional world detached from real problems and concerns. Although the Art Hall project points at some ambiguities and unresolved issues in Jaar's work it is clear that Jaar believes - as he also explained in the interview, May 2008 - that art is one of the few spaces /areas that can deal with real human concerns in a meaningful way. 


\section{A Light as Reminder - Alfredo Jaar's Lights in the City, Montreal, Canada}
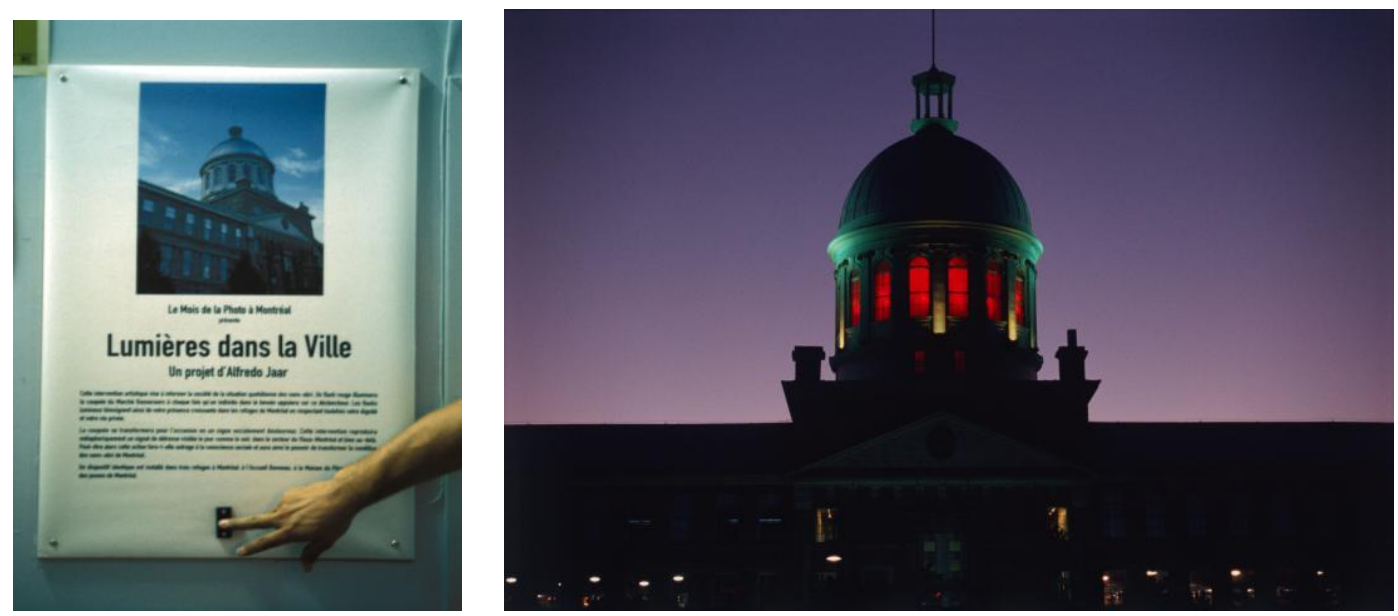

A less ambiguous work dealing with real problems in the form of public intervention outside the "white cube" is his work Lights of the City from 1999. In Lights of the City a red light from the Cupola tower in Montréal brightened and dimmed over the city. A press of a button accessible only to the homeless having entered a nearby homeless shelter would cast a light over the city, a red light, reminding its inhabitants of the city's persistent problem with the homeless. A warning light that for a moment aims to make the overlooked or dysfunctional participant of the public sphere, the homeless, visible - but not a direct visibility by representing him or her in images or words, but by the 'lightening up' or a reminding of the problem of homelessness. The homeless is in charge of the indirect representation or reminder. He/she can push the button or choose not too.

When the wandering homeless person pushes the button at one of the three shelters included in the art work, a ray of red light is cast out over the sky for a few seconds, Jaar's public art installation plays - as in Skoghall - with the idea of art as intervention and process, and art as a memorial, not only for the remembrance of a past, but as a reminding memorial for a present, and a future. The colour red flashes up and tell us something about the state of life for some people in the city. And in fact the homeless would push the button frequently sending out hundreds of "distress signals" to the citizens of Montreal (Phillips 2005, Interview, 2008).

With the piece Jaar seems to suggest that we live in times of utter forgetfulness. That we do not take the time to look around, observe, reflect and take an active responsibility for how society has developed. That we do not acknowledge the suffering of others does not only consume the homeless, but society itself as it losses its humanity. Jaar states that the red light in the Cupola, which is partly linked to the fact that the house of parliament had burned several times, in this case linked to ..." another kind of fire, one that immolates and consumes society itself." Not commemorating the dispossessed in the end consumes us all.

Several of Jaar's works creates a changing arena or space of light, darkness, color and text, concerned about actors and participants in the scenarios - as a director's sense of mise en scene (Bruckle and Mader, 2004). Alfredo Jaar operates with forms of sudden public theater and spectacle. His light and colour operate on a conceptual level, we argue, with the notions of 'glimpse' (Bruckle and Mader, 2004), 'reminder' and an 'envision and warning'. 
The development of the piece in dialogue with the homeless and the appropriation of the installation by the homeless was in one way a success. The homeless would consistently push the button making the Cupola flash hundreds of times during the evening (Phillips, 2005). They would place themselves on the agenda, but only in red light, not in humiliating images. The work received massive press and the situation of the 15000 homeless in Montreal was heavily discussed in various media channels. However, it was in other ways not so successful. In our interview with Jaar (2008), he tells about an incident one evening while dining out with friends in Montreal he witnessed an unexpected and undesirable reception of his work where drunken men cheered and applauded the flash of the red light.

After six weeks the major of Montreal, embarrassed by the project, decided to close down the installation. Jaar had wanted it to become a "permanent monument of shame" or, as he has explained, a lasting installation at least until the situation of the homeless would "be resolved" (Interview, 2008). According to Jaar the project was a failure because it only for a brief period addressed the problem and no more shelters were established. "Maybe it is naïve, but I want to change the world", Jaar declared when he spoke to us (Interview, 2008).

The idea behind the dramatic act of burning down the art hall or the red lights of Montreal was not to glorify the impermanence of being, but rather to - in the colour of danger (flames and red) - to point toward new and possible futures. While Smithson's woodshed had inspired unpredictable appropriation and debate, and is still eroding slowly, Jaar's work had interaction elements in the preparation, but the actual 'art work or project in action' had been a brief experience. Skoghall art hall existed for approximately 24 hours and had been burned down in one hour. The Montreal lights had created extensive buttonpushing, and as in Skoghall created an intense media debate, however the work lasted for approximately 6 weeks before the Mayor lost patience and cancelled the work.

The Lights in the City project was conceived and brought into actual use by a series of cooperative and interactive stages. Jaar together with the homeless temporarily re-arranged both physically and symbolically the cupola. When installed, however, various mass media companies in turn used Jaar's work and to some degree destroying its initial intensions. The media companies being more interested in depicting homeless individuals rather than the problem itself. Some of the homeless became temporarily stars in a media spectacle where the initial intention of allowing the problem of the homeless to be represented in a dignified manner, controlled by the homeless themselves, was lost. The homeless thought of participating in the media drive is unknown. It is therefore impossible to know what their thoughts are regarding the obliteration of the initial intention. What can be said is that the course of events seems to point at that the weak can only temporarily and tactically affect and alter dominant spaces and are in the end devoured or appropriated by stronger forces as Lefebvre also argues when he states that less powerful are almost always appropriated by the more powerful. 

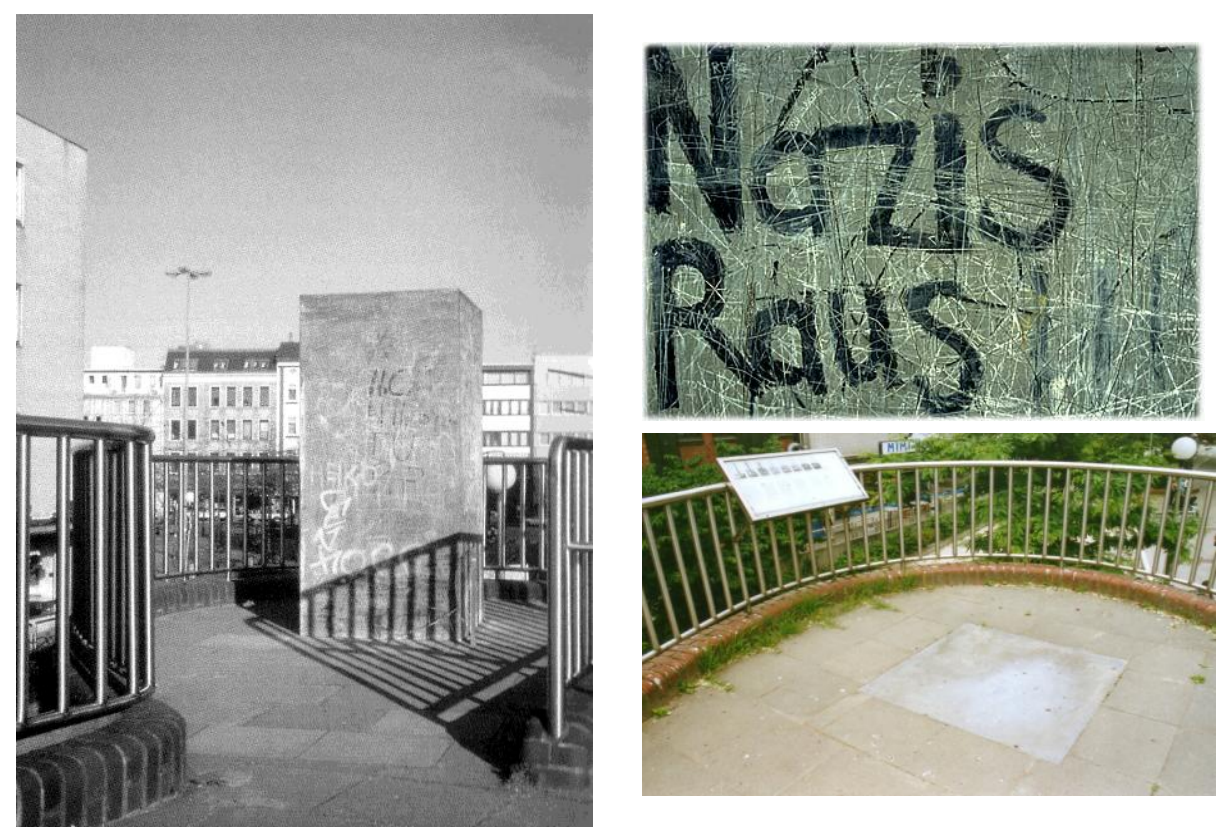

Monumental figures are usually elevated on a pedestal (Krauss, 1983) and given immortality through a presence cut out in stone. The public may pass by in awe and commemorate faithfully to the symbolic representation of an important event or figure in history. Jochen and Esther Shalev Gerz, however, challenged the idea of permanence (Young, 2000: 128) and the concept of elevation (Krauss, 1983), by turning it around: Jochen and Esther Shalev-Gerz had a twelve meter tall column (one meter wide on each side) named 'Mahnmal Gegen Fascismus' established in 1986 in a shopping area of Harburg, a suburb of Germany's $2^{\text {nd }}$ largest city Hamburg ${ }^{\text {iv }}$, in northern Germany.

A traditional monument may elevate, as noted, a figure or event to make it differ or stand out from the individual, fragmented and mundane memory. It is thereby placed in a realm of a beyond: an attempt that aims to move from the particular to the collective, a shared and public story and reference. J and E Gerz went against this sort of messaging cut out in stone and instead dumped the monument - and yet still used its traditional material (stone). They mocked and de-canonized monumental representation, by creating deliberately an ugly monument and then doing tricks with it.

Harburg was, as Skoghall, a small suburban city (where Esther Shalev Gerz later would work alongside Jaar and others as part of Public Safety, earlier mentioned), but in other ways different. The Gerzes had with Harburg chosen a suburb that contained difference and conflict to a stronger extent than Skoghall. This was not a relatively homogenous community ${ }^{v}$, but a place with huge class differences and a variety of ethnicities, in the midst of a still very cold war and a divided Germany. Harburg had a strong left as well as right, rich and poor, Esther Shalev-Gerz explained (Interview, 2008). It was a place of contrast, which the creators would test in the process of the work.

The public was invited to add their names on the twelve meter tall column that had been plated with a layer of lead allowing for inscription. The two artists had invited the public (in several languages, on an 
information board) to "add their names here to ours". "In doing so we commit ourselves to remain vigilant". When the four spaces was marked with names or/and scribble it was to be lowered into the ground for new fresh space to write on. Nobody knew how long the monument was going to be around. The artists had thereby returned the task of a memorial to its visitors: The matter or monument of concern (drawing from Latour, 2005: 7) had been returned to its public: its lifespan had not been given a ghostly, monumental presence, but a mundane life depending on the public participation, meaning that writing on the pillar would result in a process of destruction, creating a decaying physique, as the human body and memory itself. Most people may agree to be against fascism, but how does each individual put her/his belief into practice? It was up to the viewer to make the picture (Jochen Gerz, in Gerz and Shalev-Gerz, 1994). Each lowering was a public event (Gerz and Shalev-Gerz, 1994). The Stone structure had to take a bullet hole at some point, but it stayed around until 1993, seven years, and now the remembering, or the engagement against racism - and whatever other conflicts which was acted out on the 'sounding board'column - was left with the rememberer (Young, 2000). No monument can replace memory. Neither would this be about a particular memory, but about 100s of memories, many citizens' different annotations and remarks, including bullet holes, remarks as 'Lower me at last' (Lupu, 2003), 'Nazis raus', and columns of names added, as the artists had instructed. The idea of a wholesome and overarching collective memory, had been challenged by a literal and gradual lowering of the monument as a symbol of the ever-lasting representation - and instead what dotted the collective 'body' (the monument) was the plurality or diversity of the many collected memories (Young, 1993, 2000, Høg Hansen, 2005, 2008). The soundingboard had opened for many matters of concern to be reflected. The divisions and differences could on the one hand be assembled or gathered and processed on the monument. It became a public thing or ding that in principle could include all-things (Latour, 2005, 12-13, Eliasson, 2004: 120-121), meaning to be encyclopedic and archival in its approach and thereby "build the provisional and fragile assembly of our show on as many fault lines [as possible]", to borrow from Latour's Dingpolitik and apply on this context (Latour, 2005: 13).

The public became a necessary intervention in the actual life of the public art. However, any life involves as a fundamental condition its very erosion. While Jaar was aiming for letting the local publics themselves arrange future initiatives (as e.g. an art hall or shelters for homeless), Jochen and Esther Shalev-Gerz work more radically with ephemerality. The Harburg memorial had built a notion of mortality into its tangible and intangible life. A monument transformed itself from being a symbolic tombstone (Young, 1993: preface) to a literal one. Parts of the pillar is however visible in its cage. When interviewing Shalev-Gerz (2008) the interviewer (AHH) disputed the invisibility. For the Gerzes the disappearance had been crucial (Gerz and Shalev-Gerz, 1994, Shalev Gerz, 2008), but the trace of the monument and the monument is somehow still there: A small window in a door below the former memorial platform reveals the pillar and some of the scripple covering its walls. The door is closed. The stone rests in its modest mausoleum. An information board pictures the gradual lowerings (see third photo). On top of the cage the flat top of the pillar is on level with the walking path (third photo, by AHH, April 2006).

Esther Shalev-Gerz explained in 2008 that "we were a bit too close to it" and that they were "sensitive to much of the public criticism it had received". In a book from 1994 they had already commented that annotations had became more pointed, sharper and that vandalistic attacks had happened more often after the Berlin Wall went down (Gerz and Shalev-Gerz, 1994). The fall of the wall marked a turning point, she noted. Something good could come out of a disappearance of the monumental. (Interview, 2008). 
Towards the end of its life a visitor had written 'Lower me at last', on the column (as noted by Lupu, 2003). Over the years citizens had provided bullet holes, swastikas, the band name 'The Smiths' (Gerz and ShalevGerz, 1994) - and various dialogical notes, where one visitor could reply on a note from another. The documentation showed that the pillar had become a mediator and ding for many matters of concern (Latour, 2005) and much more than the invited adding of names.

According to Lupu (2003) the reception of the monument was negative. It was seen as 'Schändseule', a column of shame, and he concludes that the Harburg memorial marked the defeat of the counter memorial project (2003). For us, the agonistic character of the public debate (Wodiczko in Phillips, 2003, Mouffe, 2002) surrounding the pillar could be viewed as being a part of the concept of the memorial itself and as a well a sub-part of Germany's historikerstreit (Mayer, 1988) on its past, a debate - as any debate on history - which is also about the present.

\section{Alien Memories - Rafael Lozano Hemmer's Displaced Emperors, Linz, Austria}
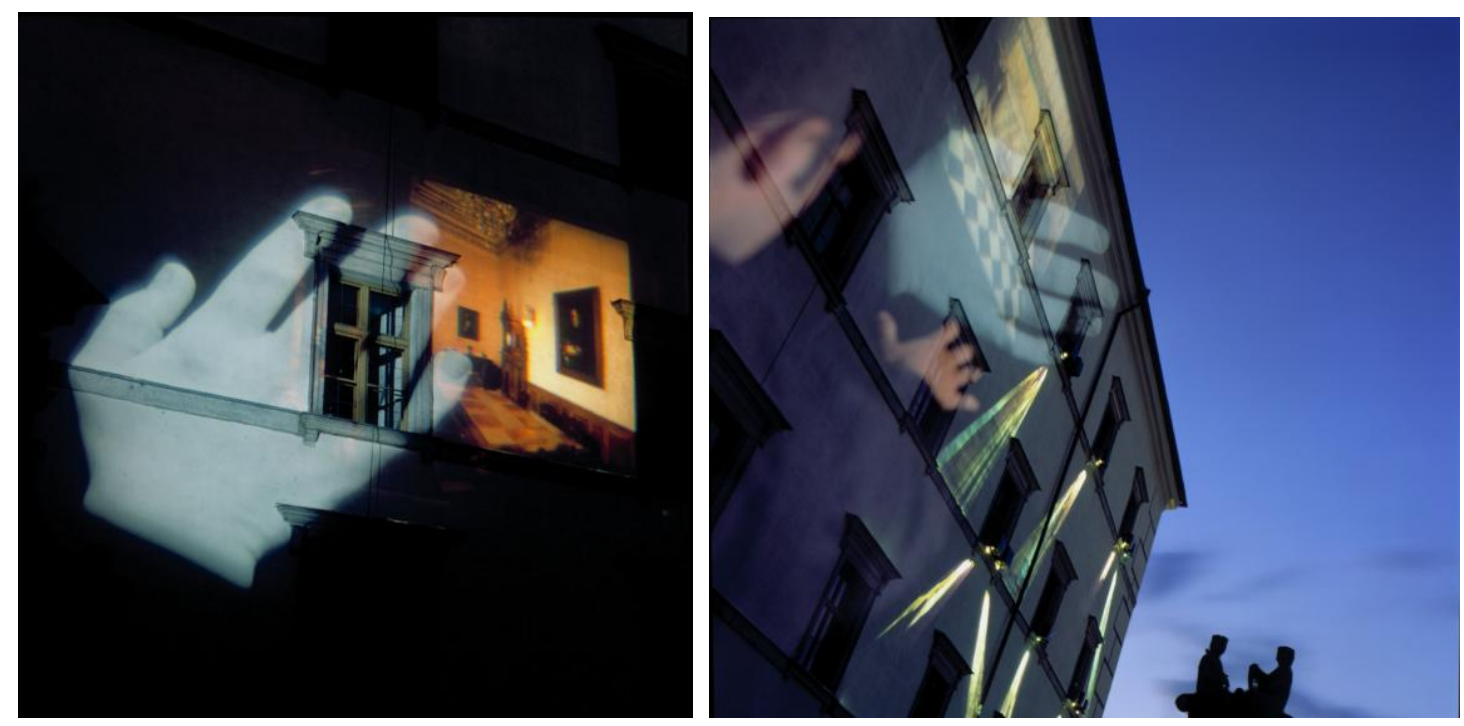

In the body of work called "Relational architecture" the media artist Rafael Lozano-Hemmer has addressed issues of cultural identity, participation, "alien memory" through re-interpreting and appropriating public spaces by engaging participants in experiencing "seepage between different layers" of experiences (Andriaansen and Brouwer 2002). Displaced Emperors by Lozano-Hemmer was set up at the Ars Electronica Festival in Linz Austria in 1997 and is part of his Relational Architecture series. It addresses through temporary appropriation of a Hapsburg castle Austrian colonial ties to Mexico and Aztec culture in the past and in the present, which are for the most part forgotten and hidden. In Lozano-Hemmer's words the piece "constructs a vector between two apparently unrelated historical oddities" (Lozano-Hemmer, 1997). These forgotten or seemingly "unrelated historical oddities" refer to how the Maximillian's castle in Linz and an Aztec feathered crown, which has been in Austrian possession since the early 1500's and currently located in Museum of Ethnology in Vienna are connected. Lozano-Hemmer explained (Interview, 
2009) that Adolf Hitler had wanted to use the castle as his retirement place - which then could be said to add another "oddity" or "alien memory" to its layers of meaning.

The pieces consisted of several interactive displacements. The first titled "Displacement \#1 - Maximilian in Mexico" engage the participants to transform the interiors of the Linz castle through overlayering images from Chapultepec Castle, which was Maximilian's residence in Mexico City. By pointing and caressing the building through a "fascist salute" (Barrios and Lozano-Hemmer 2005) while wearing wireless 3D sensors that tracks where the participants point on the façade of the Linz castle the participants activate prepared images from the interior of Maximilian's residence in Mexico City. Each room pointed at revealing a unique interior from the residence and a unique piece of music composed during the Hapsburg era. The Chapultepec Castle, which was appropriated by Maximillian to resemble his palace in Trieste, which referenced earlier Hapsburg palaces, is as such used to appropriate the Linz Castle. The visitor entering and actualizing the art project with his/her bodily act of widescreen-like projection via the sensors, marks on the one hand the scale between individual and history, the body and the urban, a living now and an ephemeral eternality. Lozano-Hemmer said he was interested in creating a "Brechtian moment" (Interview, 2009). The moment where we become conscious or realize the distance or the relation to the 'stage', or what and how the art work plays - and how we can play with it, perform identity, we could ask? The arm movement marks a deliberate doubleness. Is it a fascist salute or a caress? Lozano-Hemmer goes for the "interstitial", "the ambiguous", he says. And we add that he wants to create connections rather than confirm given, homogenous communities (Interview, 2009). After doing the caress/salute, it is all gone, ephemeral. The connection and projection is over. The participant has an experience and is left behind. "The idea of a ghost is a useful one", Lozano-Hemmer says - and adds "they [ghosts] are inside of us" (2009).

Lozano-Hemmer states in a video describing the work that "this vector of architectural quotations was indirectly a displacement of power that the Linz castle had experienced - from being a center of the Hapsburg Empire to serving as passive museum a repository of dead culture." Lozano-Hemmer took this digital palimpsest (Huyssen, 2003), which we in the case can call ghostly (re)play with colonial possessions further in his next 'displacement', another overriding, in Displaced Emperors \#2.

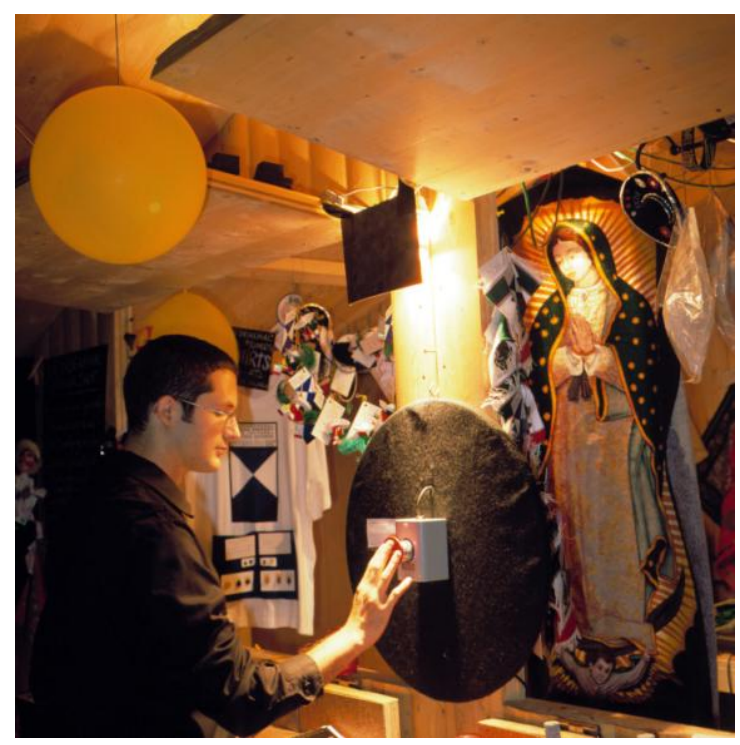


The second displacement titled Displacement \#2 - Moctezuma in Austria happened in provisional souvenir shop set up on the grounds of the Linz Castle. The souvenir shop contained cheap reproductions of cultural icons such as pyramids and sombrero hats. In the shop visitors could trigger a "temporary post-colonial override" (Lozano-Hemmer, 2008) by paying ten schillings and pressing the Moctezuma button. This act would override the overlayered interior projections triggered by the saluting participants by an image of the Aztec head-dress housed in the ethnological museum of Vienna. Simultaneously, it would also project an image of the Austrian cultural property sign on the saluting participants 'branding him or her' - leaving the participant tangled up in brands or intertwined as colonizer and colonized - an inevitable outcome of the experience of the 'meeting' between the two (Bhabha, 1994). A sign placed on Austrian buildings considered to have a high cultural value and that should be protected in the event of armed conflict.

With the staging of Displaced Emperors Lozano-Hemmer produces a micro-political world where both individuals as well as cultures are dispersed and intertwined in seemingly odd ways through constant overriding of meaning through embodied enactments. We embody memory and through our enactments re-produce colonial and imposing behavior - in this piece by making a digital caress/fascist salute and pressing a red button. Memory and memorial practices need perpetually to be performed to be kept alive. At the same time he seems to suggest that disparate projections of cultural memory should override each other. His piece also seems to suggest that we are simultaneously "victims" of random projections, which the participants physically experience when having the cultural property sign displayed onto their bodies without consent and without knowing who instigated the projection. Memorial practices are as such an ongoing process of ephemeral exchanges.

According to Lozano-Hemmer his pieces aim at establishing social and architectural relationships "where unpredicted behaviours may emerge" (Adriaansens and Brouwer 2002). He sees them as arenas - in some ways related to Latour's (2005) notion of ding, which has an artistic authorship, but this authorship has no interest in conceiving or determining the outcome. What he wishes is that the arenas fosters indeterminacy and ambiguity through apparently unexpected "seepage" between various layers of experience both on a personal and historical and global level. He states:

"Placelessness" and "multiplaces" are terms concerning the condition of the artwork, but also ourselves, and of architecture. The feeling that you belong to nowhere, and that you belong to many places at the same time. These two things are the same phenomenon" (Adriaansens and Brouwer, 2002).

He goes on stating that "Every city is many cities in one, all of them overlapping and coexisting. To LozanoHemmer belonging to multiple places at the same time and the establishing of connections between various planes of experience is attractive. "I find that very interesting, this possibility that you have in the same time and place intensely different planes of experience. The planes may be very different, but sometimes a small connection is being made, either locally or temporarily or post-geographically. There's always seepage between the different levels" (Adriaansens and Brouwer, 2002).

By projecting the Aztec head-dress owned by ethnological museum of Vienna one at first expects that the artist is criticizing a prior colonial country for possessing treasure from the colonial past. But LozanoHemmer suggests an exchange; rather than returning the Aztec head-dress the ethnological museum could give some Habsburg jewels to the Mexican state. Cultural exchange rather than cultural homogeneity may be favored? We should acknowledge how cultures are entangled and intertwined. This suggested 
exchange of gifts is not some naïve believe in kind hearted cultural exchange since it takes into account the troubled past between the countries in question.

The question is however to what degree the participants in actuality become absorbed by the intentions of the artist and become choreographed puppets so to speak and how much room they are given to reinterpret, appropriate the work or fill in the empty spaces with "alien memories" - memories that do not belong to the site. No accounts has been found describing how the Displaced Emperors was received; of how willing the participants were to embody and experience imperial colonial behavior or how they reacted to become "victims" of seemingly random events. We are of course curious on how the visitors may have pursued a final override. However, accounts exist of how other pieces in the Relational Architecture series have been received. Lozano-Hemmer points out that the installation Positioning Fear where projected shadows of pedestrians transformed a military arsenal façade in Graz, Austria, which has mural paintings from medieval times portraying the three fears of its inhabitants namely the Bubonic plague, the infestation by locusts and a possible Turkish invasion. While Lozano-Hemmer had expected a stern response the participants created humorous pantomimes. "The installation was converted into an ad hoc carnival and nobody thought for one minute about fears, plagues or invasions" (Barrios and LozanoHemmer, 2005) Along similar lines he describes that Body Movies when set up in Portugal and England generated unexpected outcomes.

\section{Conclusion}

\section{Public matters, public memories}

"We gather because we disagree", Bruno Latour noted in a public lecture in Copenhagen October 31, 2009 leading our thoughts back to the diverse, manifest and visible, public memories and quarrels of the communities the different artists entered. The question was to which extent the artists were able to lead their work and their potentials feed into, and trigger, matters of concern at Kent State, Skoghall, Montreal, Harburg, and Linz.

The dingpolitik, or assembled matters of concern (Latour 2005, 13-14) can be connected with Mouffe's (2002) notion of agonism. The agonism that Mouffe refers to is an inevitable and necessary painful but productive engagement with the strife's of the past and the present. These may point towards overcoming the divisions and antagonisms of public memory and public debate through a form of assembling that is active and public, but also acknowledges the aggregate of opinions, the scatteredness of memory and sentiment which nevertheless is brought into a public 'thing'.

A vote and an election may attempt to resolve divisions. In the case of most of the works the public 'thing' was never finished or resolved, but it was brought to light before it disappeared. The Harburg memorial slowly disappeared over seven years, like a withdrawal from a quarrel, leaving behind the rememberer, not the monument. The art hall went away in flames after 24 hours, but left a mark in the public psyche of Skoghall. The red light dimmed in Montreal after six weeks of button-pushing and public debate. LozanoHemmer's projections were temporary too, active during the Ars Electronica festival. The woodshed is still there and the site is used as a memorial ground. 
No matter their different life spans, they were about histories, or "minor histories" or "alien histories" as Lozano-Hemmer noted (Interview, 2009). Various unpredictable histories attached to them which addressed the identity of the communities where the art works took place. They were also about interrupting the present, engaging with it in innovate ways, and thereby take a step into the future - the act of making public is to gather, interrupt or to disagree to some extent, we could say paraphrasing Latour - otherwise there would be no need for a public to gather? The works all worked seductively with scale or with "connecting disparate realities" (as Lozano-Hemmer noted on his own work, 2009), when making public.

The connection of disparate realties, to elaborate on Lozano-Hemmer's point, works as a juxtaposition of flashes that connects histories, here understood as the different places of Mexico and Linz, in Austria - but also as different times, a colonial past and a present. The public matter of concern spanned over time and places, and the inherent meanings and intentionalities of the space of Linz became a central concern for the art work. Central epochs and people central to Austrian colonial and postcolonial history - which we for example can se on display as object-centered narratives in museums - is here through the participants digital and ghostly or palimpsestic (Huyssen, 1995) override connected in uncanny digitally mediated memories. The colonizer and the colonized are brought into a common appropriation or space of play. Lozano-Hemmer used the notion of the "interstitial" (Interview, 2009) - what we could also call third space (from Homi Bhabha, 1994 - who also uses the notion of the interstitial as an in-between space or coupling space of intervention and innovation).

Also Alfredo Jaar would activate the already latent and posed stories of the places for the works; the industrious character of Skoghall, the art less community?; the thousands of homeless in the freezing Montreal, a light in a dome that had burned throughout the past to push memory's trigger. The connection of red light with homelessness were done by a brief but repeating red light, as memory gone into mourning or repetition in the Freudian sense. This could also be seen as a combination of a public glimpse ${ }^{v i}$ and flash bulb $b^{\text {vii }}$ (Bourdon, 2003: 13-15), as in Skoghall, a moment with a power to provoke emotion and awake a past memory. Jaar reminded the city of Montreal of its persistent problem with homeless - and he could as well be said to point towards a haunting of the dome or the city, since the dome had been on fire many times before in the past. Jaar also reminded the inhabitants of Skoghall of its lack of art by giving them something, again briefly, and then taking it away again. Jaar's two works may be those among our examples which most directly point toward a particular public future issue - or at least holds a proposal of what one could do: establish an art hall? Establish more shelters?

\section{Time and interaction}

These public art and memorial work demonstrate the temporal character of memory, and its eroding or/and ephemeral life - and this whether we choose to look at its public and collective forms (Young, 1993) where shared narratives of a community is sought created, or its collected (Young, 1993), or fragmented and plural forms - collages that make up, and continue to remake, an individual's recollection and commemoration.

The projects all had their time mirroring that the time and life of spectacles are limited. The 'publicness' of the work is not established by placing them in public spaces or contexts, but by their ability to ignite particular processes of debate and interaction (Krause, 2008: 13) and to feed into the ebb and flow of 
public sentiment and will (Young in Krause, 2008: 25). The attempted 'publicity' was built into the very purpose of several of the examples, such as the red light of the dome in Montreal or the flames of the new art hall at its public launch reception, or the public events of the lowerings of the monument in Harburg. viii

These public events and intermissions helped to assure the potential of spectacle. In Smithson's case, however, the timely public connection and public co-creation came rather by accident through its linkage to Kent State shootings as well as continuous and troublesome American involvement in East Asia. The local and the global were fused, which again addressed the relationship between the individual and the collective, the private and the public. These works seem to suggest that memory and memorial practices need to be performed to be kept alive. The time frame that the artists operate within diverge significantly where Lozano-Hemmer favors the ephemeral while Jochen and Esther Shalev-Gerz operate with much longer processes - although impermanent.

Although all the artists share the view of public memory as an ongoing achievement full of legitimate aggregates of difference, they do so in slightly different ways. Jaar emphasize the need for society to have cultural organizations and 'shelters' that make culture visible as is apparent in the Skoghall example - and places that can protect people (shelters) in the Montreal example. For him erosion and invisibility is problematic, which can be juxtaposed to Smithson's fascination for of erosion and entropy. LozanoHemmer perhaps most insistently sees memorial practices and cultural expressions as a temporal and ephemeral practice. He seems to operate with situated memory; that ephemeral and happenstance connections between different historical pasts and different social systems or layers of experience is all that we got and can aim for. To him any form of permanence deadens culture and sucks the blood out of ongoing cultural productions. Lozano-Hemmer seems to accept the forgetfulness of memory.

\section{Choreographing volatile arenas}

The artists' aim of activating the publicness and vitality of the public arena, (a point also stressed by Latour, 2009), so it becomes an arena where public debates and interactions can be carried out makes the process more uncontrollable and the outcome unpredictable. (Artists have, of course, never controlled the reading of their work and how they are discussed by publics or within the art discourse. However, in participatory processes 'visitor' are invited to become active co-creators of the work rather than just interpreters of it). The artists' view of how such co-creative processes can be set up varies. Their strategy differs when it comes how open they are for allowing for multiple perspectives to exist within the arena, to what degree they try to choreograph the space given for co-creation and to what degree they welcome appropriation.

How the artists have dealt with the issue of appropriation, which to Lefebvre (1974/1991: 164) stands in opposition to what he calls dominated (or dominant) space, is thus of great importance. Of importance because it addresses issues of control and power and in relation to the artists envisioning of participation, co-creation and how public matters can be dealt with. To Lefebvre dominated space is generated after a master plan and transformed by technology, like a motorway 'brutalizing the land', or military architecture, or fortifications (164). True appropriation on the other hand is a form of resistance, or subversion of invitation. The practice of appropriation can also be connected to de Certeau's concept of space as concerned with temporalities and movement, and situated, earthbound tactics - opposed to the notion of place/espace propre, or a societal order of stability and its master plans or laid out strategies (de Certeau, 
1984 and Sandin, 2003). Situating the artists work as either engaging in the production of dominated or appropriated space or being engaged with strategies or tactics would be simplifying matters.

As Lefebvre notes dominant and appropriated space can be combined (Lefebvre, 1974/1991:165). Smithson, Green, Jaar, Shalev-Gerz, and Lozano-Hemmer have, when creating the arenas, in their work appropriated dominant spaces. Spaces are already invested with intentionalities and they are not blank, as Olafur Eliasson notes in the documentary Seeing Space (2009). The public artist place him or herself into that context, invitationally, by bringing his/her own intentions into play with real life participation and play with intention, and maybe even opposition to intention. (The Montreal Cupola and the Linz castle are obviously invested with intentionalities, which the artists build upon). At the same time as the artists have appropriated dominant spaces they have engaged with conceptual master plans with an invitation to appropriate. These master plans are perhaps not dominant spaces or master plans in Lefebvre's sense, but master plans nevertheless. Their work is therefore both strategic and tactical and while engaged in appropriating dominated spaces the work to various degrees simultaneously creates temporal dominated spaces that become intertwined with existing dominated spaces.

The artists obviously need to have some sort of intention, plan and strategy regarding who is to be included, when in the process and to what degree participants can engage in the co-creation. In other words, how participants are to be situated in the work. Are they situated as Eliason suggests as spectators and objects. Or in his words: "The spectator's involvement here becomes part of the objecthood of the project" (Eliasson, 2009). The notion of "spectator" and "objecthood" signals that participants are seen as passive participants that become appropriated and transformed into objects. In other words, are participants to be seen as additional probes placed on the stage constructed by the artist? Or are they situated as active subjects that have intentionality and actively engage in appropriation and are even engaged in negotiating the initial intentions?

The artists discussed here to a large degree do not open for a participatory engagement in the early and initial defining phase. Alfredo Jaar 's strategy when working with "Lights in the city" being an exception as it opens up for a co-creative process where the homeless are active participants in constructing the work in the making of the master plan itself. Both Jaar and the homeless wish to address the issue without making the homeless in to the 'objecthood of the project' or mere spectators. They are to remain subjects and engage on their own term throughout the project where their intentions and ways of being represented are respected. Ordinary citizens, political and organizational representatives of Montreal on the other hand can be seen as involved in the work as spectators and "part of the objecthood" of the work. Similarly Esther Shalev-Gerz during the Public Safety project, although defining on her own what her work should focus on, is based on a master plan that is inclusive and opens up for a participatory space where the Skoghall citizens participate as active subjects.

A more common strategy is that the artists work out the master plan. Jaar's strategy for example in the Public Safety project did not involve the citizens of Skoghall in defining what the project should be about. Initially the artists were given guided tours and they did on-site visits to the paper mill, the fire department, police station, post office, and an elementary school. When having worked out what to do the artists would set up meetings and negotiate with those to be involved in the projects. Alfredo Jaar thus negotiated with those in charge of the paper mill and the fire department. These meetings and negotiations did not alter in any significant way the initial ideas. The artist's imprint on the idea remained intact where those 
involved did so through giving a helping hand. They participated by becoming an "objecthood of the project." Both Lozano-Hemmer's Displaced Emperors and Jochen and Esther Shalev-Gerz similarly lay out the master plan without involving participants or representatives of future participants. When engaging with participatory projects who is to be involved at what time becomes a central question. There are is no easy answer to be found. However, we need to pay attention to who are involved, when they are involved, what power they are given to participate and how it affects the work.

In the same way we need to pay attention to how open the master plan or the operative work is for appropriation. While Jaar in his choreographed works tends to point toward future initiatives, such as a new permanent art hall or a new shelter for homeless, he does not create much room for reworking of the initial idea of the work. Gerz' work were also characterized by a strong and clear idea, it however laid out an uncertain continuity or a time-wise unpredictable engagement and with its form. It created a tension between the static and given monumental space and the fragmented and plural interplay with the work. Jochen and Esther Shalev-Gerz did with the vanishing Harburg memorial focus on not only the disappearance and forgetting - but also to let new disparate memories and reflections grow as what is already dead and static (the monument) disappears. The visitors could add their name or inscribe rather just reflect upon given public representations. This was a feature in Esther Shalev-Gerz' Harburg project (with Jochen Gerz) but also in her later project Public Safety, where people made wordy portraits to their own image (Portraits of Stories). She is affected by her upbringing in a "don't forget"-culture, as she puts it, that in periods in history were not allowed to represent, she explains (Interview, May 2008). "I find it interesting that you cannot really represent reality" (Sandén and Svensson, 2000). The Montreal project, the Harburg memorial, as well as Displaced Emperors are all examples of handing over representational devices in the hands of its visitors. In Skoghall, however, the visitor remained visitor - however without the fire departments direct participation, the burning could not have taken place.

In Montreal and Harburg the visitor (in Montreal the visitor to a shelter) became the one who could chose to represent him/herself or not. On the Harburg monument the visitor could picturize or write what they wanted. In Montreal you could mark your presence, but without becoming present - and instead leave it to the imagination of the citizens in the street. The visitor became a co-author or processor of the art work. By inscribing the monument or pushing the button the visitor becomes a part of the work, not a viewer. A collection (or splintering) of memories in button-pushes and inscriptions - are made collective in the concept of the artworks.

All artists share and engagement with a critical reading of the public context, as well as creating an arena where present public controversy can be temporarily voiced. Lozano-Hemmer choreographed more than Gerz and Shalev-Gerz, less than Jaar, but opens for re-reading. Gerz and Shalev-Gerz also gave opportunity for numerous overrides - in fact the traditional old media form opened for splintering and no voice or override seemed to remain or remain dominant. It would all go down in the ground. Jaar could be said to give voice or take a stance and work with this in a closely choreographed manner.

The theatricality that came to define all projects, the lining up of histories of light or names, or juxtaposing of images, new projections onto history, and not at least the flames and light in Jaar's projects lead us to end with Ranke in Benjamin: 
'To articulate the past historically does not mean to recognize it 'the way it was', Benjamin wrote, after Ranke (Benjamin, 1955/1992: 247) - and continues: 'It means to seize hold of a memory as it flashes up at a moment of danger' (247). 


\section{References}

Bammer, A. (2001), 'Hamburg Memories', The German Quarterly 74(4): 124-134.

Benjamin, W. (1992), Illuminations. London: Fontana Press.

Bhabha, H. (1994), The Location of Culture. London: Routledge.

Björgvinsson, E., and Høg Hansen, A. (2008), On Displaced Emperors and other displacements and participatory strategies - a telephone interview with Rafael Lozano-Hemmer, January, 23, 2009, Malmö - Montreal.

Björgvinsson, E., and $\mathrm{H} \varnothing \mathrm{g}$ Hansen, A. (2008), On the Skoghall Art Hall and other participatory projects a telephone interview with Alfredo Jaar May 8, 2008, Malmö - New York.

Bonnevier, L. (2007), "Skoghall har fått sin "konsthall” ". Värmlands Folkblad 3 July.

Bourdon, J., (2003) 'Some Sense of Time', History \& Memory 15(2): 5-35.

Bourriaud, N. (2002), Relational Aesthetics. Dijon: Les Presses du Reel.

Brückle, W., and Mader, R. (2004), 'Alfredo Jaar. The Mise en scene is fundamental', Camera Austria nr 86: 41-47.

Burgin, V. (1996), In/Different Spaces: Place and Memory in Visual Culture. Berkley and Los Angeles, California: University of California Press.

de Certeau, M. ( 1984), The Practice of Everyday Life. Berkley and Los Angeles, California: University of California Press.

Eliasson, O. (2004). At se sig selv sanse. Samtaler med Olafur Eliasson, Engberg-Pedersen, A. and Meyhoff, K. W., eds., Copenhagen: Informations Forlag.

Ferner, T. (2003), 'Public Safety: The tension of the unachievable meeting', http://www.jorgensvensson.se/B282FA5A-D9A7-45C5-8234-

3CDCA555FB19/Tore\%20Ferners\%20text.html (accessed April 30, 2008).

Gerz, J. and Shalev-Gerz, E. (1994), Das Harburger Mahnmal gegen Fascismus. Hamburg: Hatje.

Høg Hansen, A.( 2008), Conversation with Esther Shalev-Gerz on the Harburg memorial and the politics of memory, Gerz' studio, Paris, April 18, 2008.

Huyssen, Andreas. 1995. Present Pasts: Urban Palimpsests and the politics of memory. Stanford, California: Stanford University Press.

Høg Hansen, A. (2005), 'No Final Solution to the Memory Problem', Glocal Times, 2. http://www.glocaltimes.k3.mah.se/viewarticle.aspx?articlelD=32\&issuelD=4 
Høg Hansen, A. (2008), 'Memorials and Memory Politics in Hamburg and Haifa', in Terho, H., et al Space and History. New Perspectives on Spatiality in European History. Pisa University Press.

Krause Knight, C. (2008), Public Art. Theory, Practice and Populism. Malden, MA: Blackwell.

Krauss, R. (1983), 'Sculpture in Expanded Field', in Foster, H. ed. The Anti-Aesthetics. Essays on PostModern Culture. Port Townsend: Bay Press.

Kwon, M. (2002), One Place After Another. Site-Specific Art and Locational Identity, Cambridge, Massachusetts: MIT Press.

Latour, B. (2005), 'From Realpolitik to Dingpolitik: or How to Make Things Public', in Latour, B. and Weibel, P., eds, Making Things Public: Atmosphere of Democracy. Cambridge, Massachusetts: MIT Press, pp. 4-31.

Latour, B. (2009) 'Organizing Uncertainties; the mapping controversies project'. Public lecture, October 30, 2009, Den Fri Udstillingsbygning: Copenhagen.

Longhurst, Brian et al, eds., (2008) Introducing Cultural Studies. $2^{\text {nd }}$ edition. Pearson Longman: Harlow, England.

Lozano-Hemmer, R. (1997), 'Displaced Emperors. Relational Architecture \#2', project description. http://90.146.8.18/en/archives/festival_archive/festival_catalogs/festival_artikel.asp?iProjectID=8514\# (accessed, May 8, 2008).

Lozano-Hemmer, R. (1997), 'Displaced Emperors. Relational Architecture \#2', video recording. http://www.lozano-hemmer.com/english/projects/displaced.htm (accessed May 8, 2008).

Lozano-Hemmer, Rafael. 2008. Rafael Lozano-Hemmer official homepage, http://www.lozano-hemmer.com (accessed May 8, 2008).

Lozano-Hemmer, R. (2007), Some Things Happen More Often Than All of the Time. Turner Publishing: Nashville, TN.

Lozano-Hemmer, R. and Barrios, J. L. (2005), 'A Conversation', www.lozanohemmer.com/texts/downloadable/InterviewBarrios.doc (accessed November 13, 2009).

Adriaansens, A. and Brouwer, J. (2002), 'Alien Relationships from Public Space. A winding dialogue with Rafael Lozano-Hemmer', www.lozano-hemmer.com/texts/.../InterviewAdriaansens-Brower.doc (accessed November 13, november 2009).

Lefebvre, H. (1974/1991) The Production of Space. Oxford, UK: Blackwell.

Lupu, N. (2003) 'Memory Vanished, Absent, and Confined', History \& Memory 15(2): 130-164.

Maier, C. S. (1988), The Unmasterable Past. History, Holocaust, and German National Identity. Harvard University Press: Cambridge, Massachusetts. 
Mouffe, C. (2002) 'Democracy- Radical and Plural', CSD Bulletin, Centre for the Study of Democracy 9(1): 10-13.

Nora, P. ed (1992/1996) Realms of Memory Vol. 1: Rethinking the French Past. New York, Columbia University Press.

Phillips, P. C. (2003), 'Creating Democracy: A Dialogue with Krzysztof Wodiczko', Art Journal 62(4): 32-47.

Phillips, P. C. (2000), 'The aesthetics of witnessing: a conversation with Alfredo Jaar', Art Journal. 64(3): 6-27.

Robertson, S. 'Harburg Anti-Fascist Memorial', http://www1.uni-hamburg.de/rz3a035//antifascist.html (accessed August 10, 2009).

Sandin, G. (2003), 'Modalities of Place'. Ph.D. thesis, Lund: Lund University.

Shalev-Gerz, E. www.shalev-gerz.net (accessed 2008, the web page has since been reorganized)

Shapiro, G. (1995), Earthwards: Robert Smithsson and Art after Babel. Berkley and Los Angeles, California, University of California Press.

Sandén, P. and Svensson, J. (2000), Public Safety. Stockholm: Riksutställningar/Jörgen Svensson.

Young, J. E. (1993), The Texture of Memory: Holocaust Memorials and Meaning. New Haven: Yale University Press.

Young, J. E. (2000), At Memory's Edge. After-Images of the Holocaust in Contemporary Art and Architecture. New Haven: Yale University Press.

\footnotetext{
' Participatory approaches have evolved since the 1960s, but have recently received larger attention - for example in writings by Burgin (1996), Bourriaud (2002), Kwon, (2002), Krause Knight (2008), and Eliasson (2009).

ii Jaar's Art Hall project was part of the Public Safety project coordinated by the Skoghall-born artist Jörgen Svensson, who participated himself with Two American Policemen. Also the Spanish artist Paco Cao participated with Rent a Body, while Esther Shalev-Gerz (her Harburg project collaboration with Jochen Gerz presented elsewhere in the article), born in Lithuania, raised in Israel, and living in Paris, participated with Portraits of Stories (Sandén and Svensson, 2000, Ferner, 2003).

iii Articles in Värmland Folkblad engaging with the Public Safety project or Jaar's art hall, e.g. 31 Aug 2000, 31 Aug 2001, 17 Oct 2006, 26 Jan 2007, and 3 July 2007.

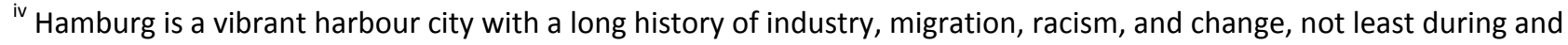
after WWII. Half of the city was burned down by allied bombing during 1943. One of the largest concentration camps, Neuengamme, was just outside the city. As Berlin and many other German sites, Hamburg is marked with history and dotted with memorials of all shapes and sizes - and the concept of the counter-memorial is largely a German 1980s phenomenon evoked at a time where Germany began more explicitly to debate their past (Lupu, 2003, Maier, 1988, Høg Hansen, 2008).
} 
${ }^{v}$ Interestingly, Esther Shalev-Gerz chose the English midlands suburb, West Bromwich, just outside England's $2^{\text {nd }}$ largest city, Birmingham, as the space for one of her recent projects. She was cooperating with the municipality in launching a public art gallery with input/art made by the public! West Bromwich is also, as Harburg, a place with a variety of ethnicities and huge gaps between rich and poor.

vi Longhurst et al (2008) summarizes differences between glimpse, glance, scan and gaze. The glimpse is 'elusively incomplete, though not necessarily fleeting' (quoting Sharatt) while the gaze is a more prolonged form of looking which again can be broken down to other forms, one is well known in theories of cinema (Longhurst et al mentions Laura Mulvey). The glance characterizes television viewing, an easily distracted practice in the domestic habitat where other things are done simultaneously. Finally, the scan, Longhurst et al notes, is associated with the operation of power in modern societies, derived from the work of Foucault and related to notions of surveillance and oversight (Longhurst et al, 2008:287-288).

${ }^{\text {vii }}$ Flash bulb memory have been used variably in the literature by psychologists and memory researchers. Drawing from Bourdon's discussion (2003: 13-15) a flash bulb memory can be a lasting and public memory with an often traumatic or strong emotional impact. By combining glimpse and flash bulb we deal with a ghostly return of a past in a brief and powerful experience. Bourdon works in particular with tv memories and mentions the assissination of President Kennedy as an example.

viii We researched for regional newspaper coverage of the Skoghall art projects and art development in Skoghall in the course of the research. Notably we found articles on Svensson's Public Safety project (where Jaar's Art Hall was a part) in Värmlands Folkblad 31 Aug 2000, 31 Aug 2001, 17 Oct 2006, 21 Oct 2006, 26 Jan 2007 and 3 July 2007. The last article, by Lena Bonnevier, reveals that an old hotel was used as café and exhibit place during 2007. 